\title{
A State Steps in the Market of Sovereign Mining on the Problem of Without Permission (PETI)
}

\author{
Alpius Sarumaha \\ Doctoral Faculty of Law \\ Brawijaya University \\ Malang, Indonesia \\ alpius_sarumaha@yahoo.com
}

\begin{abstract}
Unlicensed mining (PETI) can be defined as a mining business on all types of excavated materials with the implementation of its activities without based on the rules / rules of mining law authorized by the Central or Regional Government. Natural resource management is the right of the state to manage and control it which will be used for the benefit and prosperity of the community. One of them is about mining activities, this mining activity is regulated in Law Number 4 Year 2009 regarding Mineral and Coal Mining. Every mining business of strategic excavation and vital quarrying groups according to the Mining and Minerals Act can only be done if it has previously obtained mining permit. Those who violate the provisions of the law may be subject to criminal sanction as provided in Article 158 of Law No. 4 of 2009 Mineral and Coal Mining Initially illegal mining (PETI) in most of the territory of the State of Indonesia was undertaken by an individual or groups of people, as an additional / side effort in areas believed to potentially contain diamond, gold and tin. Increasing economic needs and expected mining operations result in better life expectancy, allowing mining actors to turn this secondary business into a major undertaking. There are several factors that are likely to affect the growth of PETI, among others, the business has been running for generations long enough, giving rise to the assumption that mining land is a legacy that does not require a business license. the business capital is relatively small and the execution of mining is done simply / traditionally without the use of high-tech equipment. the limited expertise of business actors and the limited employment opportunities, causing the mining business to be the main choice. However, any strategic mining mining business and the class of vital mining material under the Mining and Minerals Law can only be implemented if it has previously obtained mining permit these illegal activities of PETI become issues that will be discussed and become a thought in providing a way out, between the State that controls the mining materials in this case the management for the prosperity of the people of Indonesia as a whole.
\end{abstract}

Keywords- unlicensed mining (PETI), state mining sovereignty, mastery of mining materials of the people's economy

\section{INTRODUCTION}

Mining is an effort to explore the potential of natural resources that exist both in the earth's surface and in the bowels of the earth that has economic value. The economic basis of a State including the State of the Republic of Indonesia shall be determined in the Constitution. Article 33 of the Constitution of the Republic of Indonesia (UUD 1945) regulates the Indonesian economic system which reads: (1) The economy is constituted as a joint effort based on the principle of kinship. (2) Production branches that are important to the State and control over the life of the masses are controlled by the State. (3) The earth, water and natural resources contained therein shall be controlled by the State and used for the greatest prosperity of the people. The management of mining in Indonesia raises a lot of polemic in society, both among intellectuals and society in general, considering that the wealth of Indonesia is huge in the form of minerals, coal, oil and natural gas and other sources. An abundant or abundant content as mentioned before, does not provide assurances for the wealth of both the State of Indonesia and the people. In reality, the State of Indonesia can not be said to be a developed or strong country in the economy, in terms of its natural resources is quite a lot and economic value, while still quite a lot of people who live below the poverty line.

Nanang Sudrajat argued at least there are two main things that should be our joint reflection as a nation that is:

1. The quantity of natural wealth of the State of Indonesia, both its availability, and its kind varies considerably. Constitutionally it is a basic capital that should be able to create prosperity of the people of Indonesia.

2. The fulfillment of people's welfare is a very reasonable concretization of the people's demands on the function of State / Government from the result of natural wealth which has been successfully exploited from the earth of Indonesia is considered not comparable with the benefits felt by the people[1].

The polemic over the terms of allotment, management and mining results has not contributed significantly to the prosperity of the people, even impressed the members of the community where the existence of the mining management is only a spectator. There has been experience in Riau around 1997, kerosene-producing Riau, precisely the public queued for hours to get it. Mining Indonesia is a non-renewable natural wealth as a gift of God Almighty, has an important role in fulfilling the livelihood of many people. Therefore, the management must be controlled by the State to provide real added value to the national economy in an effort to achieve prosperity and prosperity of the people in justice; provide significant added value in national economic growth and sustainable regional development, it is necessary to have an independent, reliable, transparent mining regulatory reform to ensure sustainable national development[2]. 
In the Minerba Act no. 4 of 2009 actually there is an effort to provide greater opportunities for the community to join the business in the mining sector. The activities of mining communities today can not be classified as a People Mining (PR) activity, as defined in the prevailing laws and regulations. This is because it has not fulfilled the requirements, both legal and technical aspects that refer to the concept of good mining practice. Community activities that have been going on for hundreds of years have caused many problems and losses, both for the country, the environment and for themselves. The generally illegal nature of activities has been detrimental to the state's revenue side, while the environmental damage they cause has caused longterm ecosystem losses. Their limited expert ise and economic capital have led them to tend to be the object of exploitation of investors who seek to benefit from such activities. Furthermore, excavation of mine holes can cause disturbance of land and groundwater stability. In addition, it can threaten safety, because it is done work regardless of aspects of occupational health and safety. Losses also occur in the form of waste of mining resources due to inefficient processing technology applied. All that is added to the occurrence of land and river pollution due to the handling of waste processing that is not well understood. The concept of people's mining within the framework of sustainable mining resource management is based on four important aspects aimed at addressing the issues posed by mining activities, namely: (i) policy aspect; (ii) aspects of modalities; (iii) institutional / organizational aspects and (iv) technological and environmental aspects. By implementing these four aspects simultaneously, the mining activities of the people are expected to provide optimal benefits for the community and the state and at the same time can minimize the potential damage to the environment it causes.

Rule constraints also exacerbate the situation and conditions, so that the mines of the people tend to be done without permission, so vulnerable to accidents and work safety, including pollution and environmental damage that is not controlled. Based on Law No.4 of 2009 on Mineral and Coal Mining, mining classification consists of large scale mining, medium scale mining and also small scale mining in the form of people's mining. Article 20 and Article 66 to Article 73 of this Act has accommodated the interests of the people's mines because in addition to solving the problems that have been happening, on the other hand is a concrete proof of recognition of the existence of the existence of a mine of the people. If done well, it is a potential of local economy, which can drive the economy in the region.

Then two Government Regulations (PP) as the regulation of the implementation of Mineral and Coal Mining Law has been published, namely PP No.22 of 2010 on Mining Areas and PP No.24 of 2012 on the Implementation of Mineral and Coal Mining Business Activities. Article 26 and Article 27 of PP No.22 of 2010 regulates the mining area, whereas in Article 47 and Article 48 of PP No.24 of 2012 regarding the granting of People's Mining Permit (IPR). Related IPR is issued by the Regent / Mayor based on the application submitted by local residents, either individuals or community groups and / or cooperatives.

According to Law No.32 of 2009 on the Environment explained that the effort to handle the pollution problem consists of prevention and control measures. Control or mitigation efforts are to reduce the source of the heavier environmental impacts. While prevention is the effort of making environmental quality standard materials, environmental control and use of technology in an effort to overcome the problem of environmental pollution.

\section{MINING AREAS}

Article 1 number 29 of Law No. 4 of 2009 on Mineral and Coal Mining ("Law 4/2009") mentions the definition of Mining Area ("WP") as follows: Mining Area, hereinafter referred to as WP, is an area with mineral potential and / or coal and is not bound by any administrative boundaries that are part of the national spatial plan. The determinant of WP is the Government after it is determined by the local government and in consultation with the House of Representatives of the Republic of Indonesia , so that you can first check with the local Directorate General of Mineral and Coal whether your plantation area is an area categorized as WP.

\section{MINING LICENSE}

In Law No. 5 of 1960 (BAL) has been mentioned that the implementation of state control of the earth, water and natural resources contained therein can be authorized to the region. Although this provision allows the region to exercise the state's control over the earth, water and natural resources within it, it is not clear enough, especially regarding the meaning of "empowered". This is only apparent in Law No.11 of 1967 (Provision of Mining Basic Requirements / UUPP which has been replaced with Law No.4 of 2009 on Mineral and Coal Mining). The law states [3]:

a. Against the excavation class $\mathrm{C}$ execution, the control of the State and the arrangement is done by the Regional Government of Regency / City;

b. Against class B excavation materials can be submitted to the Regional Government District / City. The above provisions indicate: (1) The arrangement, management and utilization of class $\mathrm{C}$ minerals is entirely left to the regions (in this case the First Level Regions); (2) Arrangement, management and utilization of minerals of class B can be done central or regional. The authority of the region depends on the central policy.

How is the situation after the Law No.24 of 2014 on Regional Government? Since the enactment of the law, the granting of autonomy to district and municipal governments has been "widely perceived" that all mining authorities are automatically authorized by the local government. In the context of regional autonomy, not necessarily the authority and matters of mining can be submitted entirely to the local government automatically. Management tasks in the mining sector are not regional tasks, so they can not be submitted to local governments. The matters that can be submitted to the regions are local affairs, meaning they have regional values, in accordance with local conditions and not related to the national interest.

Based on the theory of licensing from Van der Pot as stated by Hagenaars, that the intervention of the Government in organizing bestuurszorg to realize welfare state, can be done in various forms of licensing, which can be grouped into three categories:

\section{Vergunning (permission)}




\section{Dispensatie (dispensation)}

\section{Concessive.}

The first form, permit (vergunning) is a decision (beschikking) granted on an activity (activity) under the legislation (algemene verbidende voorschriffuen) which requires certain procedures for the implementation of such activity. In general the activity in question is not prohibited but procedurally requires admin istrative procedures, without activity permission and is prohibited.

The second form, dispensation (dispensatie) is a decision (beschikking) which frees an act from the prohibition of the law. So in essence refuse the deed required by the legislation on the permission of the government. For example a dis pensation is given to a girl to marry under a certain age.

The third form, concessive is actually a special form of beschikking which is a permit granted to the public (public) and the public, but is given to private or state-owned enterprises (BUMN / BUMD). Basically such action without permission will be prohibited. According to van Wijk the consessie is given for activities related to "openbaar stripes" which are not able to run alone by the Government, then submitted to private companies. For example education, transportation, mining and so forth. The recipient of the concession essentially takes over some of the bestuurscorg missions of the state administration in relation to the type of modern welfare state.

The three forms of Government action are the (beschikking) arrangements made by the Govern ment for the purpose of controlling and disciplining various government activities. According to Irving Swerdlow [4], basically the licensing systemaims:

1. Laying minimum permit standards for applicant permit;

2. Limit the number of applicants by banning all forms of activity until get permission

3. To raise funds for the income of state finances.

According to Roscoe Pound, there are 3 (three) forms of interest categories:

\section{Personal Interest; \\ 2. Public Interest (Public); \\ 3. Social Interests}

Anthony I.Ogus [5] further argues that the form of a public permit depends on the object for which the permission is sought, ie the object belonging to the category of public goods and the category of public ownership. Public goods are public interest, so there is no ownership right by anyone because the object is a public goods which must be accessible and utilized by anyone, such as public transportation. Therefore, it must be controlled by the Government in order to avoid a monopoly in the utilization of the intended public interest. Such matter is related to Article 33 paragraph (2) of the 1945 Constitution of the Republic of Indonesia, which mandates that the production branches which are important for the state and which affect the livelihood of the public are controlled by the State. Therefore, a permit granted in connection with an activity involving a public interest must be granted with a public license made by an authorized public institution.

The second form, public ownership where in the nature of public interest (public interest) there is public ownership (community), which means contained the meaning of property rights of all people or property of the nation. Thus the permit granted will have an impact on the great authority and related matters, therefore it is necessary to define the rights and obligations of the licensee made in the agreement. Such matter is related to Article 33 paragraph (3) of the 1945 Constitution of the Republic of Indonesia which mandates that the earth and water and natural resources contained therein shall be controlled by the state and used for the greatest prosperity of the people.

Judging from the theory as proposed by Anthony I. Ougus [5], goods that contain the meaning of public interest (public interest) there are two kinds of classified public goods and public ownership. Public Goods implies that the goods have the meaning of public interest and the goods have none, so the Government is obliged to control the utilization through various licenses in the form of vergunning (permit). Public ownership implies that the goods have the meaning of public interest and the goods are owned by all the people, so it should be able to provide benefits and welfare for all people equally. Therefore, the use and utilization of such goods should basically be implemented by the Government itself. If the government has not or is unable to implement it by itself, it must be controlled by the Government through various licenses in the form of concessie (concession). Permission granted will have an impact on the great authority and various matters related to the rights and obligations of the licensee.

Natural resources belong to the public ownership, because it contains the sense of belonging to the entire nation, it needs to be controlled by the government so that its use can be aimed for as big as the prosperity of the people as its owner. So basically it must be implemented by the Government itself, except under certain conditions it can be given permission to certain parties to carry out the management of mining. In accordance with the licensing theory as adopted in the Netherlands, licensing concerning public ownership can be given in the form of concessie followed by granting various rights and obligations to the concession holder as outlined in an agreement. The is suance of concessie must remain through the prior approval of the Minister as the party representing the right of state control, so it is facultative. The recipient of the concession essentially takes over some of the bestuurszorg missions of the state administration in relation to the type of modern welfare state.

Handling and government steps in tackling the problem of illegal gold mining.

Dealing with illegal mining is not an easy matter. Many illegal mining is done by large groups of small people and involving the parties who have the power. In addition, with the enactment of Law no. 4 of 2009 on Minerals and Coal, has placed the requirement of the people's mining business permit as well as the technical requirements applied to the company, so that the community will not be able to fulfill the human, capital and technology needs, since in general the people's mining activities are carried out traditionally by technique - conventional mining techniques. Moreover, with the people's mining obligations implemented in the community mining areas (WPR) does not necessarily guarantee the availability of abundant mining materials in the mining permit areas of the people, so the potential losses suffered by the people's mining are quite large. Some of these factors are the drivers of the emergence of traditional 
gold mining practices by the people, especially the weakeconomy people with limited skills

Things experienced by law enforcement officers in tackling the rampant illegal gold mining include the following:

1. Limited resources of Polri organization, deployment of Polri's human resources deficiency in the effort to overcome illegal gold mining practice such as example in Bengka Regency which is still far from expectation. This is evident from some indications that law enforcement efforts against illegal gold mining operators are still not running optimally. One of them is reflected from the limited personnel who have qualifications and specifications in the field of mining and the environment. In addition, budget support and infrastructure facilities supporting investigation and investigation of criminal acts in the field of mining are still inadequate. In addition to issues related to human resources readiness, budget and infrastructure, the methods applied in tackling criminal acts in the mining sector have not been running optimally, it is seen from the efforts to overcome illegal gold mining practices are more likely to put forward the repressive aspect rather than doing the steps prevention through a persuasive approach to the community. In addition, law enforcement efforts in the field of mining are only charged to the perpetrators who are caught redhanded illegal gold mining activities, while the cukong and pengepuloften free from legal bondage.

2. Overlapping of land ownership permits issued by the central and regional governments. One of the obstacles in the effort to overcome illegal gold mining practices is related to the process of permitting the management of mineral resources, which until now still often found overlapping forest management licenses with mining areas, so it is not uncommon to find illegal gold mining practices on forest areas that are included in Forest Concession Rights (HPH) of a company. Where the rampant illegal gold mining activities in the region can not be separated from the number of mining companies that have a Mining Business License (IUP) that does not immediately perform production activities. Weak system of government supervision, where during this time there are many companies whose lifetime IUP is dead but still can do mining activities.

3. Sectoral policies that are partial and not holistic in law enforcement of illegal gold mining. Observing the complexity of problems in the field of illegal mining, of course, need to be supported by a comprehensive policy between agencies in law enforcement criminal acts in the field of mining. Nevertheless, the fact remains that there is a difference of interpretation between components of Criminal Justice System(CJS) to the articles in Law no. 4 of 2009 on Mineral and Coal Mining, so there is often a difference of perception in the application of criminal sanctions against illegal gold mining actors which resulted in the process of completing the case becomes protracted. In addition, there is an internal policy in the Attorney General's Office which regulates the Polri's notice of commencement of investigation (SPDP) which must be submitted to the prosecutor's office, which makes the investigation process less effective.

4. Community legal culture. In addition to the problems faced by the problem of socio-economic condition of miners, the rampant illegal gold mining practices are also caused by the low level of public knowledge of mining laws and regulations, in addition to the adat culture that recognizes customary / traditional land tenure, handling permits in the field of mining, the level of comple xity and bureaucracy in the management of mining permits (IPR) and the mindset of mining entrepreneurs who do not have permission.

\section{CONCLUSION}

1. The government needs to socialize related regulations, given knowledge and ease in obtaining licenses to the public.

2. There needs to be a comprehensive policy among agencies in law enforcement of criminal acts in the field of mining, to equate perceptions in the application of criminal sanctions against illegal gold mining actors.

3. There needs to be harmonization, rounding and consolidation of each draft regulation that should involve the Ministry of Justice and Human Rights, to prevent overlapping of land ownership permits is sued by the central and regional governments. At the time of the enactment of the law should involve related parties, this is in line with Law no. 12 Year 2011 on the establishment of legislation.

4. There must be professional law enforcement officers, budget support and infrastructure either in the form of software or hardware supporting investigation and investigation of criminal acts in the field of mining.

\section{REFERENCES}

[1] N. Sudrajat, Teori dan Praktik Pertambangan Indonesia Menumt Hukum Indonesia. Yogyakarta: Pustaka Yustisia, 2010.

[2] Law of the Republic of Indonesia Number 4 Year 2009 regarding Mineral and CoalMining. .

[3] Article 33 of the Constitution of the Republic of Indonesia (UUD 1945). .

[4] I. Swerdlow, The Public Administration Of Economic Development. New York: Praeger Publishers inc, 1975.

[5] A. I. Ogus, Regulation Legal Fom and Economic Theory. Oregon: Hart Publishing, 2004. 